\title{
PENERAPAN METODE ENAM TOPI BERPIKIR DE BONO DALAM PEMBELAJARAN BERDISKUSI (Kuasi Eksperimen pada Siswa Kelas XI SMK Negeri 13 Bandung Tahun Ajaran 2009/2010)
}

\author{
Ratna Rizky Wulandari \\ Universitas Pendidikan Indonesia \\ Email: ratnarizkyw@gmail.com
}

\begin{abstract}
Abstrak
Penelitian ini bertujuan untuk mengetahui kemampua siswa dalam; (1) berdiskusi sebelum diberi metode enam topi berpikir De Bono di kelas eksperimen dan sebelum diberi metode diskusi kelompok di kelas kontrol, (2) berdiskusi setelah diberi metode enam topi berpikir di kelas eksperimen dan setelah diberi metode diskusi kelompok di kelas kontrol, dan (3) untuk mengetahui ada tidaknya perbedaan yang signifikan antara kemampuan siswa dalam berdiskusi yang diberi metode enam topi berpikir De Bono di kelas eksperimen dengan yang diberi metode diskusi kelompok di kelas kontrol. Penelitian ini merupakan penelitian dengan menggunakan metode kuasi eksperimen. Dengan populasi seluruh siswa XI SMK Negeri 13 Bandung tahun ajaran 2009/2010, dengan sampel kelas eksperimen siswa kelas IX AK 5 dan sampel kelas kontrol siswa kelas IX AK 3. Hasil penelitian ini membuktikan bahwa ada perbedaan yang signifikan antara kelas yang diberi metode Enam topi berpikir (kelas eksperimen) dengan kelas yang diberi metode diskusi kelompok (kelas kontrol). Hal ini dapat dilihat dari uji t yang dilakukan pada data posttest kelas eksperimen dan kelas kontrol dengan mengambil taraf signifikansi $(\alpha)$ sebesar 0,05 diperoleh bahwa nilai signifikansi (2-tailed) sebesar 0,000 disebabkan 0,000 $<0,05$, maka $\mathrm{H}_{0}$ ditolak. Hal ini menunjukkan bahwa terdapat perbedaan yang signifikan antara kelas ekperimen yang menggunakan metode enam topi berpikir De Bono dengan kelas kontrol yang memakai metode diskusi kelompok. Dari perolehan angka tersebut dapat disimpulkan metode enam topi berpikir mampu meningkatkan keterampilan berbicara siswa dalam berdiskusi.
\end{abstract}

Kata Kunci: Enam topi berpikir, topi berpikir, De Bono, dan berdiskusi

\begin{abstract}
This study aims to determine the student ability; (1) consulted before the given method of six hats thinking De Bono in the experimental class and the prior given group discussion method in the control class, (2) a discussion after the given method of six hats thinking in the experimental class and after being given a group discussion method in the control class, and (3) to determine whether there is a significant difference between the ability of students in a discussion by the six hats method of thinking De Bono in the experimental class by group discussion method in the control class. This research is using a quasi-experimental methods. With the entire student population XI SMK Negeri 13 Bandung 2009/2010 academic year, with samples of the experimental class students of class IX AK 5 and grade control sample class IX students AK 3. The results of this study prove that there is a significant difference between the classes by the method Six hats think (experimental class) with classes by group discussion method (control group). It can be seen from the $t$ test performed on the data posttest experimental class and control class by taking a significance level $(\alpha)$ of 0.05 was obtained that the value of significance (2-tailed) of 0.000 because $0.000<0.05$, then $\mathrm{HO}$ is rejected. This shows that there are significant differences between the experimental class using the six thinking hats De Bono with control class that uses
\end{abstract}


group discussion method. From these figures we can conclude the acquisition of the six hats method of thinking can improve students' speaking skills in discussions.

Keywords: Six thinking hats, caps thinking, De Bono, and discussion

\section{PENDAHULUAN}

Komunikasi erat kaitannya dengan keterampilan berbicara karena setiap individu yang melakukan ujaran mempunyai maksud tertentu untuk dipahami oleh lawan bicara sehingga pesan yang dimaksud dapat tersampaikan. Dalam sistem ini, individu saling bertukar pendapat, gagasan, perasaan, dan keinginan dengan bantuan lambang yang disebut dengan "Kata". Kata inilah yang menjadi kekuatan sebuah kalimat efektif dalam berbicara. Hal tersebut dapat memudahkan komunikasi yang terjadi antarindividu sehingga pesan yang dimaksud dapat tersampaikan. Oleh karena itu, untuk menuangkan gagasan dalam berkomunikasi diperlukan keterampilan berbicara yang baik.

Di samping keterampilan menyimak, membaca, dan menulis, keterampilan berbicara merupakan salah satu aspek keterampilan berbahasa. Keterampilan berbahasa tersebut tidak bisa dipisahkan antara satu dengan yang lainnya. Hal ini sesuai dengan pendapat Tarigan (2008:1) bahwa "Setiap keterampilan itu erat sekali kaitannya dengan tiga keterampilan lainnya de-ngan cara yang beraneka ragam". Contoh keterkaitan tersebut dapat dilihat dari keterampilan berbicara yang didahului oleh keterampilan menyimak. Tarigan (2008:3) menyatakan "Berbicara adalah suatu keterampilan berbahasa yang berkembang pada kehidupan anak yang hanya didahului oleh keterampilan menyimak dan pada masa tersebutlah kemampuan berbicara atau berujar dipelajari." Pada awalnya, manusia belajar berbicara berdasarkan lambang bunyi yang disimaknya, kemudian mengucap- kan kata-kata tersebut dan akhirnya dapat berbahasa. Hal ini menandakan bahwa berbicara merupakan keterampilan yang mudah dilakukan dan keterampilan yang penting untuk dikuasai. Albert dalam Tarigan (2008:28-29) menyatakan "Kemampuan berbicara secara aktif merupakan suatu unaur penting terhadap keberhasilan kita dalam semua bidang kehidupan."

Faktanya, berbicara merupakan hal yang sulit untuk dilakukan terutama ketika mengemukakan gagasan dan berbicara di depan umum. Kesulitan berbicara tersebut dapat dilihat dari siswa yang tidak berani mengemukakan gagasannya dalam pembelajaran berbicara di sekolah. Contohnya pada saat pembelajaran berdiskusi di sekolah, masih banyak siswa yang memilih untuk mendengarkan daripada mengemukakan gagasannya. Padahal, pembelajaran berdiskusi merupakan sarana untuk belajar mengeluarkan gagasan, menanggapi gagasan secara kritis dan mempertahankan gagasan sendiri dengan argumentasi secara logis dan dapat dipertanggungjawabkan. Terdapat beberapa faktor yang menjadikan siswa sulit mengemukakan gagasan pada saat berdiskusi. Pertama, karena belum adanya keberanian dan rasa percaya diri yang tumbuh pada diri setiap siswa, kedua karena siswa merasa takut salah ketika mengemukakan pendapat di depan umum, dan ketiga karena siswa merasa bingung ketika mengemukakan pendapatnya.

Untuk menanggulangi masalah ini, dibutuhkan metode yang dapat membantu siswa untuk mengemukakan pendapatnya dengan baik. Salah satu 
metode pembelajaran yang dapat merangsang siswa untuk mengemukakan pendapatnya dari berbagai sudut pandang, yaitu metode enam topi berpikir De Bono.

Berdasarkan latar belakang di atas, tulisan ini menguraikan bagaimana kemampuan siswa dalam pembelajaran berdiskusi sebelum dan sesudah diberi metode enam topi berpikir De Bono di kelas eksperimen, sebelum dan sesudah diberi metode diskusi kelompok di kelas kontrol. Bagaimana perbedaan signifikan antara kemampuan siswa tersebut.

\section{KAJIAN TEORETIS}

\section{A. Hakikat Berbicara}

Berbicara merupakan hal yang tidak bisa ditinggalkan oleh manusia karena tujuan utama dari berbicara adalah untuk berkomunikasi. Berbicara merupakan keterampilan yang langsung berhubungan dengan objek yang dituju untuk menyampaikan pesan yang dimaksud. Berbicara menurut Tarigan (2008:16) adalah "Suatu kemampuan mengucapkan bunyi-bunyi artikulasi atau kata-kata untuk mengekspresikan, mengatakan, serta menyampaikan pikiran, gagasan, dan perasaan." Lebih lanjut lagi Tarigan mengatakan bahwa berbicara merupakan suatu bentuk perilaku manusia yang memanfaatkan faktor fisik, psikologis, neorologis, semantik, dan linguistik sedemikian ekstesif secara luas sehingga dapat di-anggap sebagai alat manusia yang paling penting bagi kontrol sosial".

Dari beberapa pendapat tersebut dapat disimpulkan bahwa pada hakikatnya berbicara adalah suatu keterampilan dalam berbahasa yang menggunakan lisan dan membutuhkan kecakapan dalam mengekspresikan pikiran, gagasan yang ada pada otaknya untuk menyampaikan pesan kepada seseorang atau kelompok orang dengan tujuan tertentu.

\section{B. Diskusi Kelompok Sebagai Sarana Latihan Berbicara}

Diskusi berasal dari bahasa latin distcutere, yang berarti "Membeberkan masalah". Dalam Kamus Besar Bahasa Indonesia (KBBI) pengertian diskusi adalah "Pertemuan ilmiah untuk bertukar pikiran mengenai suatu masalah". Kosasih (2009:78) mengartikan diskusi sebagai "Bentuk bertukar pikiran untuk membicarakan suatu masalah." Hendrikus (1991:96) mengartikan diskusi berarti "Memberikan jawaban atas pertanyaan atau pembicaraan serius tentang suatu masalah objektif." Tarigan (2008:40) mengartikan diskusi adalah "Suatu kegiatan kerjasama atau aktivitas koordinatif yang mengandung langkahlangkah da-sar tertentu yang harus dipatuhi oleh seluruh kelompok." Menurut Widyamartaya (1980:20) diskusi ada-lah "Bercakap-cakap membicarakan suatu hal, suatu masalah, dan mencari jalan keluar atau pemecahannya." sedangkan diskusi menurut Suhendar dan Supinah (1992-:107) adalah "Proses pelibatan dua atau lebih individu yang berinteraksi secara verbal dan saling berhadapan muka, mengenai tujuan atau saran tertentu melalui cara tukar menukar informasi, pengelolaan sendiri, atau pemecahan masalah". Dari pengertian tersebut dapat disimpulkan bahwa diskusi merupakan sebuah metode untuk memecahkan masalah secara lisan dengan cara bertukar pikiran dalam sebuah kelompok.

Diskusi ini merupakan salah satu sarana untuk meningkatkan kemampuan berbicara karena orang-orang yang terlibat dalam sebuah diskusi akan mengungkapkan pendapatnya masingmasing. Dalam situasi ini, perbedaan pendapat akan terjadi karena masing- 
masing mempunyai keinginan untuk menyelesaikan masalah yang sedang dibahas. Pada saat itulah kemampuan berbicara akan tergali. Selain itu juga, wawasan yang dimiliki oleh orang yang sedang berdiskusi akan terlihat. Hal ini sependapat dengan John Stuart dalam Tarigan (2008:40) mengatakan bahwa:

"Satu-satunya cara, tempat dimana manusia dapat mengemukakan beberapa pendekatan untuk mengetahui keseluruhan pokok pembicaraan adalah dengan jalan mengetahui segala hal yang dikatakan oleh orang-orang yang mempunyai pendapat-pendapat yang berbeda."

Pernyataan di atas dapat disimpulkan bahwa berdiskusi meru-pakan cara yang tepat untuk mengetahui seberapa besar kemampuan berbicara yang dimiliki seseorang karena dengan perbedaan pendapat tersebut dapat terlihat kemampuan dalam menguasai topik yang sedang dibahas.

\section{Metode Enam Topi Berikir De Bono}

Edward De Bono seorang pakar terkemuka dalam mengajarkan keterampilan berpikir dan penggagas konsep berpikir lateral kemudian mengembangkan teknik-teknik formal tersebut menjadi teknik kreatif. Dalam bukunya yang berjudul "Revolusi Berpikir" (2007) pada tahun 1993 menggambarkan metode berpikir kreatif yaitu metode Enam Topi Berpikir. Dalam buku ini, De Bono memusatkan pemikir untuk berpikir dalam satu jalur atau dapat disebut berpikir paralel. Dalam artikelnya Hidayat (2008) mengatakan bahwa berpikir paralel berarti "Mengondisikan agar orang-orang yang bekerja dalam tim bisa berpikir ke arah yang sama, dengan 'jalur' berpikir yang sama". Berpikir paralel merupakan berpikir yang mengaharuskan berpikir dari satu 'jalur' atau 'sudut' yang tetap untuk menghindari kerancuan. Apabila seseorang berpikir pada jurusan yang sama maka hasil pemikirannya pun akan menjadi lebih optimal.

Dalam metode ini terdapat berbagai warna yang dijadikan topi untuk berpikir. Setiap warna mewakili satu jenis kegiatan berpikir. Warna-Warna tersebut antara lain putih, merah, hitam, kuning, hijau, dan biru. Untuk mengetahui bagaimana cara kerja dari setiap topi itu, akan dipaparkan di bawah ini.

\section{1) Topi Putih}

Topi putih melambangkan berpikir secara netral dan objektif, bukan argumen atau usul. Fokus topi putih adalah informasi yang ada. Hal-hal yang mencakup topi putih antara lain a) Informasi apa yang dimiliki? b) Informasi apa yang tidak ada? c) Bagaimana cara memperoleh informasi yang dibutuhkan?

\section{2) Topi Merah}

Topi merah melambangkan perasaan, intuisi, dan emosi. Topi merah dapat dikatakan sebagai lawan dari topi putih. Tujuan topi merah adalah memberi kesempatan kepada peserta untuk mengeluarkan perasaan sehingga perasaan tersebut dapat menjadi bagian dari keputusan yang akan diambil. Hal-hal yang berkaitan dengan perasaan biasanya merupakan perasaan pembenaran, situasi saat ini, dan keragu-raguan.

\section{3) Topi Hitam}

Topi hitam adalah dasar dalam berpikir kritis. Berpikir kritis adalah berpikir dengan menilai baik dan buruk.. Beberapa contoh pertanyaan yang dapat digunakan pada saat menggunakan topi hitam adalah sebagai berikut: a) Apakah ini benar? b) Apakah ini cocok? c) Apakah ini akan berhasil? d) Apa resikonya dan apa masalahnya?

\section{4) Topi Kuning}


Warna kuning melambangkan sinar matahari dan optimisme. Dengan menggunakan topi kuning, peserta diskusi dapat mencari mencari nilai, manfaat, dan alasan suatu fungsi. Dengan kata lain, menggunakan topi kuning berarti berpikir positif tentang sesuatu. Contoh pertanyaan yang diungkapkan pada saat memakai topi kuning antara lain: a) Apa manfaatnya? b) Mengapa ini pasti berhasil?

\section{5) Topi Hijau}

Topi Hijau mencerminkan pertumbuhan, energi dan kehidupan. To-pi hijau adalah topi produktif, generatif, kreatif, dan inovatif. Manfaat untuk topi hijau antara lain eksplorasi, usul dan saran, alternatf, ide-de baru, provokasi, aksi dan energi

\section{6) Topi Biru}

Topi biru adalah pandangan menyeluruh yang mengontrol proses. Topi biru mencakup hal-hal sebagai berikut. a) Di mana posisi kita sekarang? b) Apa langkah selanjutnya? c) Simpulan d) Pengamatan dan komentar (De Bono, 2007:95-117).

\section{Keuntungan Memakai Metode Enam Topi Berpikir De Bono}

Metode enam topi beripikr De Bono ini memiliki banyak keuntungan karena metode ini diciptakan untuk berpikir dalam satu jalur pemikiran yang bermanfaat untuk metode memecahkan masalah. Metode ini bukan metode yang memaksa seseorang untuk berpikir dengan berbagai warna, tetapi metode ini menawarkan pemikiran dengan satu jenis berpikir pada satu saat agar pandangan seseorang tersebut terhadap suatu masalah dapat disikapi dalam frame berpikir yang sama. Keuntungan metode enam topi beripikr De Bono dalam artikel Hidayat (2008) yang berjudul "Six Thinking Hats, Enam Topi Pemikir " adalah sebagai berikut.

1) Menciptakan kesamaan kondisi pemikiran, sehingga tercipta 'bahasa pemikiran' yang sama, mengoptimalkan kerja otak, dan fokus.

2) Diversity, keragaman pemikiran banyak orang akan menghasilkan pemikiran lebih baik.

3) Membantu anggota tim untuk berpikir tanpa dipengaruhi karakternya. Dengan menggunakan metode ini seseorang yang berpikir akan sulit untuk menghadirkan karakternya karena setiap orang yang menggunakan metode ini sudah mempunyai jalur berpikir yang sudah ditentukan oleh warna topi.

4) Menghilangkan "Ego" masing-masing orang. Setiap orang yang berpikir, akan memikirkan suatu masalah secara objektif. "Ego" yang ada akan terhapus karena setiap orang akan berpikir dengan jalur berpikir metode ini.

5) Mengurangi perdebatan. Metode ini merupakan metode yang mempunyai aturan main yang jelas. Ketua kelompok mempunyai wewenang untuk mengatur waktu dalam berpikir untuk mengungkapkan pendapatnya, sehingga setiap orang fokus terhadap pendapatnya masing-masing.

6) Memaksa kita mengoptimalkan masing-masing otak karena setiap orang menggunakan topi yang berbeda-beda.

\section{E. Langkah-langkah Menggunakan Metode Enam Topi Beripikr De Bono}

Dalam memakai metode enam topi beripikr De Bono terdapat dua cara untuk menggunakannya, antara lain penggunaan sesuai dengan kebutuhan sesaat dan penggunaan yang sistematis. 


\section{Penggunaan sesuai dengan kebu- tuhan sesaat.}

Penggunaan sesuai kebutuhan sesaat ini merupakan hal yang paling umum terjadi. Suatu saat salah satu topi dapat digunakan untuk mengganti topi lainnya. Di sini orang dapat menyarankan penggantian topi sesuai dengan kebutuhan pemecahan masalah yang ada. Topi yang disarankan mungkin hanya akan dipakai selama dua atau tiga menit saja, selanjutnya pemikir dapat menggantinya sesuai dengan kebutuhan. Topi itu memberi jalan untuk mengganti alur pemikiran.

\section{Penggunaan yang sistematis}

Dalam situasi ini, urutan penggunaan topi berpikir sudah diatur sebelumnya dan pemikir menjalaninya sesuai dengan urutan. Hal ini dilakukan apabila ada kebutuhan untuk membahas suatu subjek secara cepat dan efektif. Urutan itu ditentukan dengan menggunakan topi biru yang merancang program tentang masalah yang menjadi subjek. Metode ini juga bermanfaat apabila ada pertengkaran atau ketidaksepahaman antara individu terhadap satu hal dan individu-individu itu tidak menggunakan cara berpikir yang benar. Penggunaan yang berurutan ini dapat ditentukan sendiri dengan aturan sebagai berikut.

a. Setiap topi dapat digunakan lebih dari satu kali.

b. Umumnya yang terbaik adalah menggunakan topi kuning sebelum menggunakan topi hitam karena sulit bersikap poitif setelah bersikap penuh kritik.

c. Topi hitam digunakan dengan dua cara. Yang pertama adalah untuk menunjukkan kelemahan suatu ide. Dengan demikian, topi ini harus diikuti oleh topi hijau, yang bertugas mencari cara mengatasi kelemahan.
Yang kedua adalah penggunaan topi hitam untuk melakukan penilaian.

d. Topi hitam selalu digunakan untuk penilaian terakhir terhadap suatu ide. Penilaian terakhir ini selalu harus diikuti oleh topi merah. Tujuannya adalah agar pemikir dan peserta lain mengetahui bagaimana perasaannya tentang ide itu setelah menilainya.

e. Jika ada perasaan tertentu yang kuat tentang sesuatu subjek, pakailah topi merah untuk mengeluarkan perasaan-perasaan itu.

f. Jika tidak ada perasaan-perasaan yang mengganggu, segera gunakan topi putih untuk mengumpulkan informasi. Setelah topi putih, gunakan topi hijau untuk memunculkan berbagai alternatif. Kemudian, timbang alternatif itu dengan menggunakan topi kuning, diikuti oleh topi hitam. Lalu, pilih satu alternatif dan pertimbangkan alternatif itu dengan topi hitam, kemudian topi merah (De Bono, 2007:121).

De Bono (2007:122) mengatakan "Perbedaan utama urutan-urutan di atas adalah perbedaan antar dua situasi yaitu mencari ide dan bereaksi terhadap satu ide".

\section{METODE PENELITIAN}

Metode penelitian yang digunakan dalam penelitian ini adalah metode eksperimen. "Metode eksperimen merupakan metode penelitian yang menguji hipotesis berbentuk hubungan sebab akibat melalui pemanipulasian variabel independen (misal treatment, stimulus, kondisi) dan menguji perubahan yang diakibatkan oleh pemanipulasian tadi" (Subana, 2001:95). Eksperimen yang akan digunakan dalam penelitian ini adalah eksperimen semu atau biasa disebut dengan eksperimen kuasi. Eksperimen kuasi ini muncul karena penelitian 
terhadap ilmu sosial secara umum dan bidang bahasa secara khusus tidak realistis apabila hanya dibatasi pada rancangan kebenaran eksperimental. Penelitian bahasa dihadapkan berbagai persoalan yang sangat rumit, seperti sikap manusia, pembelajaran bahasa, dan sikap bahasa yang sewaktu-waktu dapat berubah. Penggunaan metode ekspermen kuasi dalam penelitian ini disesuaikan dengan tujuan penelitian, yaitu menguji penerapan metode enam topi beripikr De Bono dalam pembelajaran berdiskusi. Metode eksperimen yang penulis gunakan adalah nonequivalent control group design. Metode ini hampir sama dengan pretest posttest control group design, hanya saja pada metode ini kelas eksperimen dan kelas kontrol tidak dipilih secara random melainkan dengan kriteria tertentu. Model ini membutukan dua kelas dalam penelitiannya, satu kelas eksperimen dan satu kelas kontrol sebagai pembanding penelitian. Tabel desainya adalah sebagai berikut:

\section{Tabel 1 \\ Pola Penelitian}

\begin{tabular}{|c|c|c|c|}
\hline $\mathrm{E}$ & $\mathrm{O}_{1}$ & $\mathrm{X}$ & $\mathrm{O}_{2}$ \\
\hline $\mathrm{K}$ & $0_{3}$ & & $\mathrm{O}_{4}$ \\
\hline
\end{tabular}

(Sugiyono, 2008:116)

$\mathrm{E}=$ Kelompok Eksperimen

$\mathrm{K}=$ Kelompok kontrol

$\mathrm{O}_{1} \quad=$ Pretest , tes yang dilakukan sebelum eksperimen

$\mathrm{O}_{2} \quad=$ Posttest, tes yang dilakukan setelah eksperimen

$\mathrm{X}=$ Perlakuan

Desain di atas menggambarkan bahwa tes yang digunakan dalam penelitian ini dilakukan sebanyak dua kali pada kelas eksperimen (E) maupun kelas kontrol (K). Pertama tes yang dilakukan sebelum perlakuan atau biasa disebut pretest $\left(\mathrm{O}_{1}\right)$. Pretest ini dilakukan di kelas eksperimen maupun kelas kontrol untuk mengukur kemampuan awal siswa. Kedua tes yang dilakukan setelah perlakuan atau biasa disebut posttest $\left(\mathrm{O}_{2}\right)$. Posttest ini dilakukan setelah perlakuan (X) dengan metode enam topi beripikr De Bono yang diterapkan di kelas eksperimen sedangkan perlakuan di kelas kontrol dilakukan dengan memakai metode diskusi kelompok.

\section{HASIL DAN PEMBAHASAN}

Untuk menerapkan metode enam topi berpikir ini guru menyediakan replika topi yang terbuat dari kertas lipat berwarna hitam, merah, kuning, hijau, biru, dan putih. Siswa dibagi dalam tiga kelompok diskusi untuk membahas tema-tema yang berbeda. Setiap kelompok memiliki satu orang ketua yang akan memandu anggotanya menentukan urutan topi mana saja yang akan dipakai dalam berdiskusi. Setelah itu setiap kelompok memaparkan hasil diskusi di dalam kelompoknya di depan kelas. Siswa lain menyimak dan menanggapi hasil diskusi tersebut.

Penilaian dilakukan dengan cara merekam semua aktivitas diskusi yang selanjutnya ditranskrip ke dalam bentuk tulisan. Penilaian tersebut didasarkan pada aspek kualitas gagasan, kuantitas isi gagsan, kuantitas berpendapat, santun dalam berbahasa, hubungan isi dengan topik, toleransi dalam berpendapat, dan kelancaran berbicara.

Berdasarkan hasil penghitungan yang diperoleh, dapat diketahui rata-rata nilai pretest siswa di kelas eksperimen sebesar 55,8 dan rata-rata nilai pretest siswa di kelas kontrol sebesar 55,29. Data tersebut menunjukkan bahwa tidak ada perbedaan yang berarti pada kemampuan awal siswa di kelas eksperimen maupun kelas kontrol atau 
dalam kata lain, kemampuan awal siswa di kelas eksperimen dan kelas kontrol sama.

Untuk mengetahui kemampuan akhir siswa setelah diberi metode enam topi berpikir De Bono pada kelas eksperimen dan metode diskusi kelompok pada kelas kontrol, selanjutnya siswa tersebut mengikuti posttest. Berdasarkan perhitungan tersebut didapatkan rata-rata kedua kelas mengalami peningkatan dibandingkan pretest. Ratarata kelas eksperimen berubah menjadi 78,4 dan kelas kontrol berubah menjadi 65,95 . Hal ini menunjukkan bahwa nilai rata-rata kelas yang diberi metode enam topi berpikir De Bono lebih besar dari nilai rata-rata kelas yang diberi metode diskusi kelompok.

Setelah mengetahui rata-rata baik pretest maupun posttest di kelas eksperimen dan kelas kontrol, kemudian diadakan uji antar penimbang (ANAVA). Hal ini dilakukan untuk menghindari subjektifitas yang tinggi antar penilai satu dan penilai lainnya. Dari hasil penghitungan tersebut didapatkan nilai reliabilitas antar penimbang untuk data nilai pretest dan posttest di kelas eksperimen secara berturut-turut adalah 0,94 dan 0,81 . Berdasarkan tabel Guilford, koefisien reliabilitas antar-penimbang untuk nilai seperti itu termasuk dalam korelasi sangat tinggi. Untuk uji reliabilitas antarpenimbang di kelas kontrol didapatkan nilai pretest dan posttest 0,93 dan 0,79. Berdasarkan tabel Guilford, koefisien reliabilitas antarpenimbang untuk nilai seperti itu termasuk dalam korelasi sangat tinggi dan tinggi.

Hasil perhitungan normalitas menunjukkan bahwa data pretest pada kelas eksperimen pada nilai pretest tidak berdistribusi normal karena nilai signifikansi $<0.05$, karena $0,04<0,05$ dapat disimpulkan bahwa sampel pada kelas eksperimen berasal dari populasi yang tidak berdistribusi normal, sedangkan pada kelas kontrol sampel berasal dari populasi yang berdistribusi normal. Hal ini dapat terlihat dari nilai signifikansi > 0,05 , karena $0,062>0,05$ dapat disimpulkan bahwa sampel di kelas kontrol pada nilai pretest ini berasal dari populasi yang berdistribusi normal.

Selanjutnya, karena data kedua kelas tidak sama, ada yang berdistribusi normal dan ada data yang tidak berdistribusi normal, maka langkah selanjutnya adalah menguji kesamaan dua rata-rata memakai uji KolmogorovSmirnov dengan mengambil taraf signifikansi $(\alpha)$ sebesar 0,05. Dari hasil penghitungan tersebut didapatkan nilai 0,854 . Hal ini menunjukkan bahwa tidak terdapat perbedaan rata-rata skor pretest kelas eksperimen dan kelas kontrol karena $0,854>0,05$.

Untuk mengetahui normalitas data posttest, dilakukan hal yang sama seperti uji normalitas pada data pretest. Hasil penghitungan uji normalitas data posttest di kelas eksperimen kelas kontrol menunjukkan sampel berasal dari populasi yang berdistribusi normal. Hal ini dapat dilihat dari nilai signifikansi kelas eksperimen dan kontrol berturut-turut sebesar 0,2 dan 0,104 . Nilai $0,2>0,05$ dan 0,104 >0,05.

Hal yang dilakukan selanjutnya adalah uji homogenitas nilai posttest. Uji ini dilakukan untuk mengetahui apakah masing-masing data yang diperoleh dari kedua kelas sampel memiliki varians populasi yang sama atau berbeda, dengan mengambil taraf signifikansi 0,05. Dari penghitungan dengan menggunakan uji One Way Anova didapat nilai signifikansi 0,000 , karena $0,000<0.05$ maka dapat disimpulkan bahwa ketiga varian berbeda.

Setelah mengetahui nilai signifikansi pada uji homogenitas, hal yang 
selanjutnya dilakukan adalah uji t. Uji t ini merupakan pembuktian dari hipotesis yang ada pada penelitian ini, apakah terdapat perbedaan yang signifikan antara kelas yang diberi metode enam topi berpikir De Bono dengan kelas yang tidak diberi metode enam topi berpikir De Bono. Dari hasil penghitungan uji $\mathrm{t}$ ini didapatkan nilai signifikansi 0,000 , karena $0,000<0,005$ maka $\mathrm{H}_{0}$ ditolak. Hal ini dapat disimpulkan bahwa terdapat perbedaan yang signifikan antara kelas yang diberi metode enam topi berpikir De Bono dengan kelas yang tidak diberi metode enam topi berpikir De Bono.

\section{SIMPULAN}

Berdasarkan keseluruhan analisis yang telah dibahas baik data kuantitatif maupun data kualitatif maka diperoleh simpulan akhir, yaitu Kemampuan awal siswa dalam berdiskusi baik di kelas eksperimen yang menggunakan metode enam topi berpikir maupun kelas kontrol yang menggunakan metode diskusi kelompok mempunyai kesamaan. Kemampuan akhir siswa setelah diberi perlakuan di kelas eksperimen maupun kontrol meningkat dibandingkan pada saat pretest. Hal ini membuktikan bahwa terdapat peningkatan kemampuan keterampilan berbicara siswa di kelas eksperimen maupun kelas kontrol. Akan tetapi, rata-rata nilai kelas eksperimen yang memakai metode enam topi berpikir De Bono lebih besar dibandingkan dengan kelas kontrol yang hanya diberi metode diskusi kelompok. Setelah dilakukan perhitungan uji normalitas dan uji homegenitas bahwa terdapat perbedaan yang signifikan antara kemampuan berdiskusi siswa yang diberi metode enam topi berpikir De Bono di kelas eksperimen dengan kemampuan siswa yang diberi metode diskusi kelompok di kelas kontrol. Hal ini pun sekaligus menjawab bahwa metode enam topi berpikir De Bono dapat meningkatkan keterampilan berbicara siswa pada saat berdiskusi.

\section{DAFTAR PUSTAKA}

Akdon. (2007). Modul aplikasi statistika dalam pendidikan. Bandung: Program Megister Pendidikan Dasar Universitas Pendidikan Indonesia.

Arikunto, S. (2006). Prosedur penelitian suatu pendekatan praktik. Jakarta: Rineka Cipta.

De Dono, Edward. (2007). Revolusi berpikir. Bandung: KAIFA.

Depotter, Bobbi. 2007. Quantum learning. Bandung: Kaifa.

Direktorat akademik UPI. 2010. Panduan program latihan profesi ( $p l p)$. Bandung; direktorat akademik UPI.

Haryonosuyono.blogspot.com/2007/03/.1 aporan-mengikuti-festival-ofthinker-kedua-di-abu-dhabi-2124oktober.

Hendrikus, Dori. (1991). Retorika Terampil berpidato, berdiskusi, berargumentasi, dan bernegoisasi. Yogyakarta: KANISIUS.

http/luqmanbaehaqi.blogspot.com/2008/ 03/.topi-ajaib.html.topi-ajaib. Senin, 10 Maret.

Iskandarwassid \& Suhendar. (2008). Strategi pembelajaran bahasa. Bandung: ROSDA.

Kosasih, E. (2008). Terampil berbicara di depan umum. Jakarta: Nobel

Machfoedz. Mahmud. (2005). Rapat dan persentasi lisan yang efektif. Yogyakarta: ANDI.

Margono,S. 2004. Metodologi penelitian pendidikan. Jakarta: Rineka Cipta 
Nurgyantoro, Burhan. (2001). Penilaian dalam pengajaran bahasa dan sastra. Yogyakarta: BPFE Yogyakarta.

Syamsudin dan Damaianti, Vismaia. 2007. Metodologi pendidikan bahasa. Bandung: Rosda.

Pratama, Reza. 2006. Penerapan model futsal dalam pembelajaran berbicara pada siswa kelas 1 sma kartika 2 bandung.Skripsi UPI. Tidak diterbitkan.

Priyatno, D. (2008). Mandiri belajar spps untuk analisis data dan uji statistik. Yogyakarta: Media com

Rakhmat, Jalaludin. (2001). Retorika modern pendekatan praktis. Bandung: PT. Remaja Rosdakarya.

Saptiah, Siti. 2008. Penerapan metode de bono dalam pembelajaran bahasa di taman kanak-kanak (studi kasus di tk ummul mukminin soreang). Skripsi Upi. Tidak Diterbitkan.

Nurfatia, Elis. (2009). Pembelajaran berbicara dengan menggunakan teknik "hembusan angin kencang" (studi kuasi eksperimen pada siswa x sma kartika siliwangi 3 bandung tahun ajaran 2008/2009). Skripsi Upi, Tidak diterbitkan.

Subana dan Sudrajat.(2001). Dasardasar penelitian ilimiah. Bandung: Pustaka Setia

Sudjana, (1992). Metoda statistika. Bandung: TARSITO.

Suhendar \& Supinah. (1992). Pengajaran dan ujian keterampilan menyimak dan keterampilan berbicara. Bandung: Pionir Jaya

Universitas Pendidikan Indonesia. (2009). Pedoman penulisan karya ilmiah. Bandung: Tidak diterbitkan.

Widyamartaya. (1980). Kreatif berwicara.Yogyakarta:

KANISIUS. 